\title{
MODERATING ROLE OF JOB SATISFACTION ON THE RELATION BETWEEN PARTICIPATIVE LEADERSHIP STYLES AND PERFORMANCE IN A PETROCHEMICAL COMPANY
}

\author{
Heri Sapari Kahpi*1, Mirza Abdi Khairusy², Zaenal Abidin³, Anis Fuad \\ Salam ${ }^{1}$ \\ 1Sekolah Tinggi Ilmu Ekonomi Banten, Indonesia \\ 2Universitas Banten Jaya, Indonesia \\ 35ekolah Tinggi Ilmu Administrasi Banten, Indonesia
}

\begin{abstract}
The implementation of participative leadership style has been positive on the increase in employee performance. However, how it works in an extraction and refining petrochemical firm is still elusive. This study investigates how a participatory leadership style may support employee performance as moderated by Job Satisfaction. Primary data from all 85 HRD employees in Cilegon Petrochemical Company is selected as a database. This study computes the relationships using the PLS-SEM procedure. This study proves that participative leadership style variables significantly influence employee performance, job satisfaction has a significant positive effect on employee performance, and job satisfaction moderates the effect of participative leadership style on employee performance.
\end{abstract}

Keywords: Participatory Leadership Style, Job Satisfaction and Employee Performance, Human Resource

*Corresponding author : heri.kahpi1976@gmail.com

DOI: $10.24252 /$ minds.v7i2.16846

ISSN-E: 2597-6990

ISSN-P: 2442-4951

http://journal.uin-alauddin.ac.id/index.php/minds 


\section{INTRODUCTION}

Human resource management practice requires leadership skills to manage. In other words, it takes leadership and managers as a whole in the organization. Leadership is needed for the implementation of the program in human resources practice (Hijriah, 2016). An organization will achieve its goals and programs if people who work in the organization can do their jobs properly in their respective fields and responsibilities. People who work in these organizations can carry out their duties properly, and it is necessary to have a leader who can influence and direct all available resources towards achieving goals (Putra et al., 2013).

One factor that can support the achievement of improved employee performance is the leadership style. According to Iqbal et al. (2015), leadership is a practice in which the executive directs, guides, and influences others' actions and work to enable them to achieve the desired results in certain circumstances. An effective leadership style in a company is needed to improve its employees' performance so that they are willing to work together and want to follow orders properly according to what they want and support the achievement of work goals and tasks within the allotted time. Leaders who can carry out their leadership with persuasion, cooperation, and motivate their subordinates to participate in decision making openly will improve their employees' performance (Insan \& Yuniawan, 2016). Ojokuku et al. (2012) regard leadership behavior or style as a way or approach to providing direction, implement plans and motivate people.

According to Hasibuan (2008), Participatory leadership is if a leader carrying out his leadership is carried out persuasively, creating harmonious cooperation, and fostering his subordinates' loyalty and participation. In line with research, Rana et al. (2019) stated that a participatory leadership style is a crucial factor affecting employee performance. A leadership style that asks and uses subordinates' suggestions for decision making. Participatory leader behavior expects suggestions from subordinates in the decision-making process. Thus, subordinates feel more valued by their superiors because they can play a role in decision making. With this leadership style, the relationship between leaders and subordinates will be maintained (Putra et al., 2013).

Someone with reasonable job satisfaction will like his job satisfaction in general, where an employee feels treated properly and believes that his job has much compliance with the wishes (Akehurst et al., 2008). Such confidence shows that work is a critical factor in determining one's job satisfaction. Besides, research conducted by Fitrianasari et al. (2013) shows that an increase in job satisfaction precedes an increase in employee performance. According to Robbins and Judge (2014), job satisfaction serves as a positive feeling on a job, which is the impact/results of evaluations of various aspects. Job Satisfaction is a significant dimension of employee welfare and a crucial indicator in achieving organizational success (Culbertson, 2009).

Discussions on job performance in terms of participating in leadership need to be further explained through research. Previous researches on 
participatory leadership result in diverse employee performance and the existence of gap research. Iqbal et al. (2015) research show that the leadership style of participation has the most influence in the long run, and its effect on employees is positive. These results are in line with research (Lumbasi et al., 2016; Putra et al., 2013; Rana et al., 2019) that found an influence of participatory leadership style on employee performance. According to Gaver et al. (1995), different studies stated that participatory leadership styles would be unproductive in the short term. In line with research (Insan \& Yuniawan, 2016; Jiputra, 2019) shows that participatory leadership style does not affect employee performance. According to Sari et al. (2014), each organization must have a different level of satisfaction by the system and values adopted by all organizations. Job satisfaction always gets a vital place for organizational behavior. So with a participatory leadership style, employee satisfaction variables will provide improved performance.

\section{THEORETICAL REVIEW}

\section{Participative Leadership}

Northouse (2001) argues that leaders' participatory leadership style invites and encourages employees to play an essential role in the decisionmaking process, even though the power of final decision-making lies with the leaders vice versa. Lumbasi et al. (2016) suggested that participatory leadership styles that involve management collaborate with employees in the decisionmaking process resulting in high-quality decisions. Mullins (2007) that participative leadership is a leader that encourages employees' active involvement in organizations, expressing creativity, and expressing the abilities and talents of employees. This participative leadership style variable is operationally measured using three dimensions, i.e., consultation, communication, and explanation (Rana et al., 2019).

An effective leadership style in a company is needed to improve its employees' performance so that they are willing to work together and want to follow orders properly by what they want and support the achievement of work goals and tasks within the allotted time (Jiputra, 2019). With the right leadership style, subordinates will respect the work and are willing to make the best contribution. Accuracy in delivering tasks according to subordinates' capacity and capabilities will encourage task implementers to try to maximize the performance charged to employees (Rokib \& Santoso, 2018). According to Fatokun et al. (2010), there is a good relationship between leaders and subordinates to create mutual respect and work efficiency. This idea is in line with the research conducted (Fitriani, 2013; Junaidi et al., 2020; Newman et al., 2016), states that participatory leadership styles affect employee performance, and as such:

$\mathrm{H}_{1}$ : Participatory leadership style increases employee performance. 
Job Satisfaction

Job satisfaction is employees' attitude towards their work, and job satisfaction is individual because each individual has different satisfaction (Fitrianasari et al., 2013). Job satisfaction is a collection of feelings and beliefs held by an employee, both pleasant (positive emotions) and unpleasant (negative emotions) about their work (Nur, 2013). According to Rivai et al. (2014), that job satisfaction is an assessment that reflects someone's feelings of pleasure or displeasure, satisfaction, or dissatisfaction in taking a job. Job satisfaction is an attitude towards each employee's work, both pleasant and unpleasant in his work. Job satisfaction is measured by several dimensions, i.e., satisfaction with salary, cooperation with closest colleagues and superiors, remuneration policy, satisfaction with the nature of work (Lekić et al., 2019).

Job satisfaction is an individual's general attitude towards his work and is something individual (Robbin \& Judge, 2014), whereas according to Luthans (2006), job satisfaction is effectiveness or emotional response to various aspects of work. Employees always aspire to respect in the workplace to achieve goals. Job satisfaction is assumed to reflect their participative leadership style to create a healthy and effective workplace for employees to improve employee performance ultimately, and thus:

$\mathrm{H}_{2}$ : Job satisfaction moderates a participative leadership style on performance.

\section{Employee performance}

Setiawan (2017) states that performance is the result achieved by someone carrying out their duties and responsibilities according to each company's standards/organization. Mangkunegara (2016) stated that performance is the work of the quality and quantity achieved by an employee in carrying out their duties per the responsibilities given to him. Performance results from work done by someone in a certain period in carrying out the tasks and responsibilities given to achieve a goal (Sari \& Susilo, 2018). This study measures it by the quantity, quality, and timeliness of the work. Figure 1 presents the conceptual model in this study.

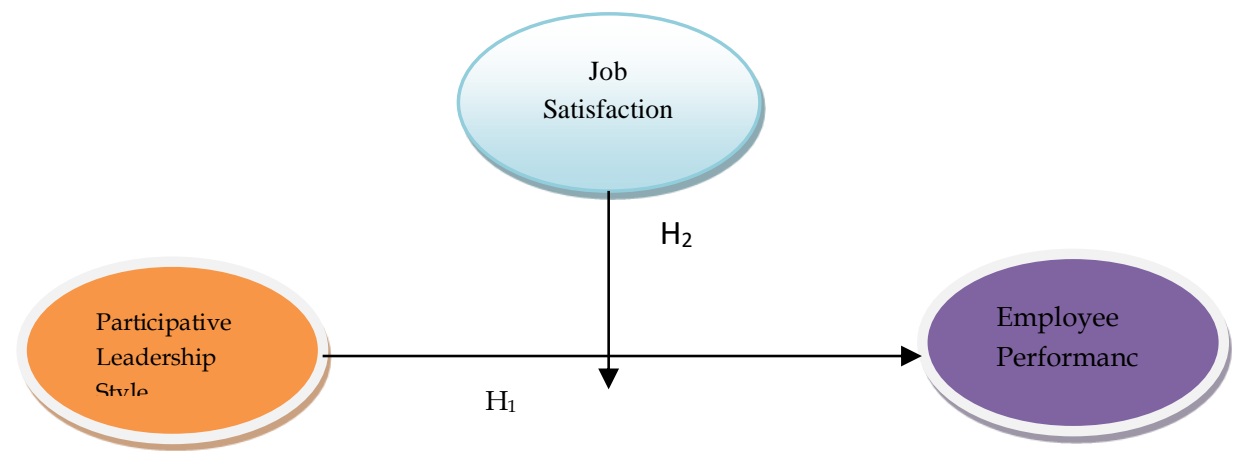

Figure 1. Conceptual Framework 


\section{METHODOLOGY}

Measurement of participating leadership refers to Rana et al., 2019, which is indicated by consultation, communication to encourage employees' role to participate, and logical and acceptable explanations of any decision making. Job satisfaction is measured based on theories put forward by Lekić et al. (2019) such as salaries, coworkers and superiors, remuneration, and employment. Job performance is measured by quantity, quality, and timeliness. Determination of the sample using a total sampling technique, amounting to 85 employees of the HRD department. In this study, an interval scale was used Agree-Disagree Scale technique, where there is a scale sequence of 1 (Strongly Disagree) to 10 (Strongly Agree) for all variables. This scaling is selected considering the habitual mindset of the Indonesian people accustomed to numbers 1-10 to make it easier for respondents to give assessment questions (Wisudaningsi et al., 2019). The analytical method used to test hypotheses is SEM. PLS-SEM is a superior social science problem method and is suitable for small samples and non-normal data (Hamdollah \& Baghaei, 2016). PLS examines two models, the outer and inner models, to get results of hypothesis testing

\section{RESULTS}

\section{Outer Model Results}

The SmartPLS SEM test analysis in this study was used to determine the relationship between participative leadership style, job satisfaction, and employee performance variables. The results of the analysis of the SEM SmartPLS model are as follows :

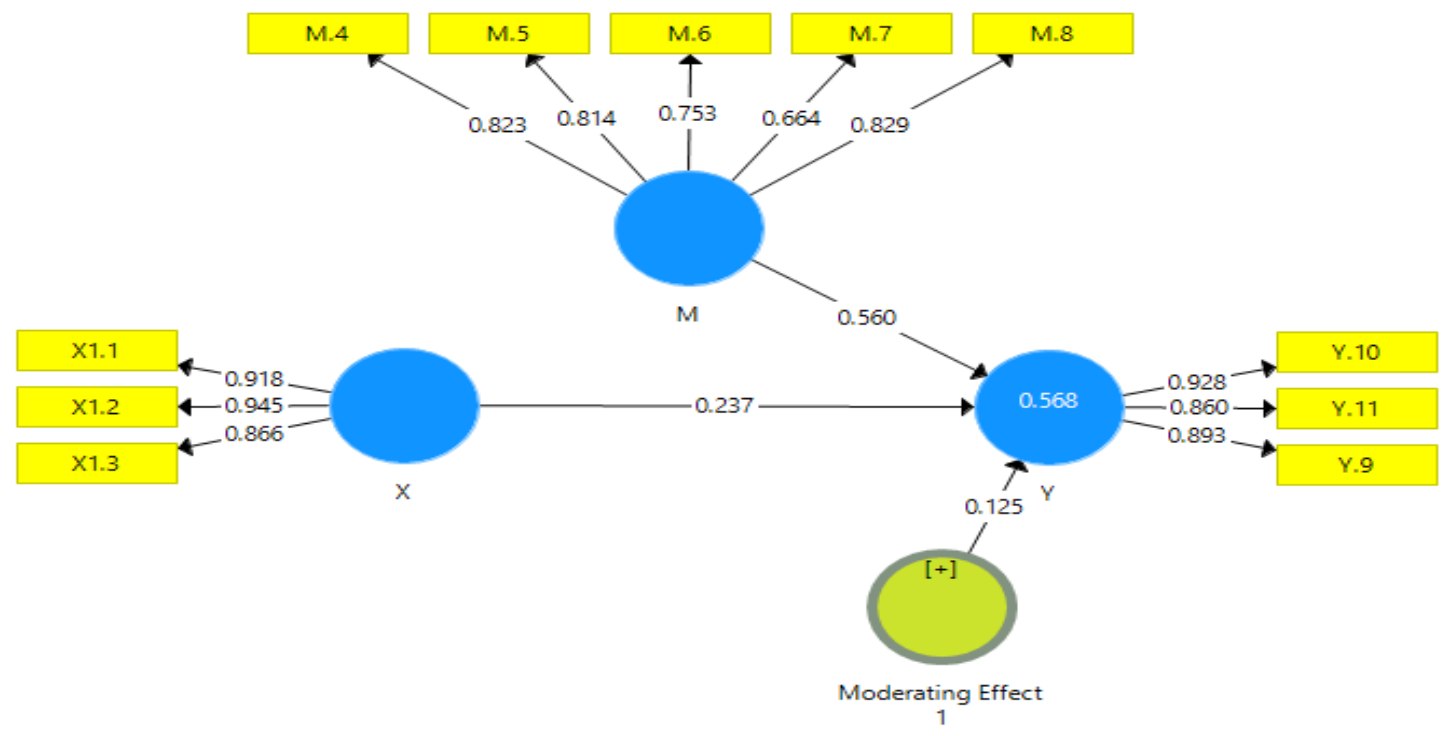

Figure 2. Model Result

Figure 2 reveals that the loading factor for the construct of Participatory Leadership Style, Job Satisfaction, and Employee Performance above is required from 0.5 to 0.6 . Based on the analysis results, all items have a loading factor value 
greater than 0.5 so that all constructs of Participatory Leadership Style, Job Satisfaction, and Employee Performance have good validity. Furthermore, the reliability measurement can be traced by Composite Reliability's value above 0.70 and Average Variance Extracted (AVE) above 0.5. Table 1 compiles the results of outer model testing.

Table 1 Composite Reliability dan Average Variance Extracted (AVE)

\begin{tabular}{lcc}
\hline \multicolumn{1}{c}{ Variable } & Composite Reliability & AVE \\
\hline Job Satisfaction (M) & 0,885 & 0,607 \\
Moderating Effect 1 & 1,000 & 1,000 \\
Participative Leadership Style (X) & 0,935 & 0,828 \\
Employee Performance (Y) & 0,923 & 0,799 \\
\hline
\end{tabular}

Source: Smartpls output

Table 1 above shows the composite reliability results and the AVE of each construct is good because of Composite Reliability's values $>0.70$ and AVE $>0,05$. The results of discriminant validity testing are by the cross-loading value, which is presented in table 2 .

Table 2. Discriminant Validity

\begin{tabular}{cccc}
\hline & Participatory leadership & Job Satisfaction & Job performance \\
\hline X1.1 & 0.918 & 0,254 & 0,576 \\
X1.2 & 0.945 & 0,354 & 0,461 \\
X1.3 & 0.866 & 0,556 & 0,500 \\
M.4 & 0,416 & 0.823 & 0,562 \\
M.5 & 0,168 & 0.814 & 0,297 \\
M.6 & 0,372 & 0.753 & 0,508 \\
M.7 & 0,388 & 0.664 & 0,549 \\
M.8 & 0,459 & 0.829 & 0,562 \\
Y1.1 & 0,576 & 0,695 & 0,928 \\
Y1.2 & 0,461 & 0,651 & 0,860 \\
Y1.3 & 0,500 & 0,442 & 0,893 \\
\hline
\end{tabular}

Source: Smartpls output

Based on the table above, it can be seen that the indicators X1.1-X1.3 have the highest correlation with the variable participating in leadership (X1). M4-M8 indicators have the highest correlation with the Job satisfaction variable $(\mathrm{M})$; the Y1.1-Y1.3 indicators have the highest correlation with the Job performance variable $(\mathrm{Y})$. So it can be concluded that the discriminant validity is good. The model test for the structural model (inner model) is presented in table 3. 
Table 3. R-Square

\begin{tabular}{cc}
\hline Variable & R-square \\
\hline Employee Performance (Y) & 0,568
\end{tabular}

Source: Smartpls output

Table 2. shows the R-square value for the Employee Performance Variable (Y) obtained at 0.568 . These results indicate that $56.8 \%$ of Employee Performance Variables (Y) are influenced by Participative Leadership Styles' Variables and job satisfaction's moderating effect. Three main aspects are used in assessing the validity of convergence, namely loading factor, composite reliability (CR), and extracted average (AVE) (Hair et al., 2011). This procedure is carried out as suggested by Hair et al. (2011) for items that have a loading between 0.40 and 0.70 to increase the reliability of composites on a reflective scale. Hypothesis testing can be observed in table 4 .

Table. 3 Result For Inner Weights

\begin{tabular}{|c|c|c|c|c|c|}
\hline Correlation & $\begin{array}{l}\text { Original } \\
\text { Sample } \\
\text { (O) }\end{array}$ & $\begin{array}{l}\text { Sample } \\
\text { Mean } \\
(\mathrm{M})\end{array}$ & $\begin{array}{l}\text { Standard } \\
\text { deviation }\end{array}$ & T-Value & $\begin{array}{l}\text { P- } \\
\text { Value }\end{array}$ \\
\hline Job Satisfaction $(\mathrm{M}) \rightarrow$ & 0,560 & 0,555 & 0,091 & 6,168 & 0,000 \\
\hline Employee Performance (Y) & & & & & \\
\hline 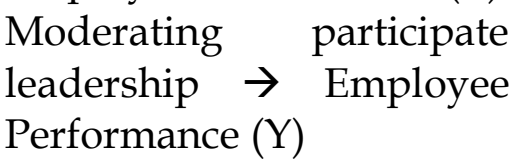 & 0,125 & 0,122 & 0,062 & 2,028 & 0,043 \\
\hline 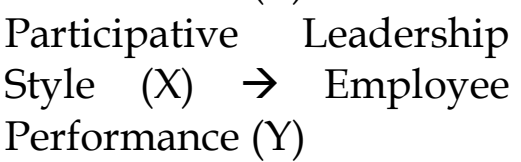 & 0,237 & 0,241 & 0,092 & 2,569 & 0,010 \\
\hline
\end{tabular}

Source: Smartpls output

Based on Table. 3 above regarding hypothesis testing can be explained that:

1. Hypothesis testing results on the influence of participatory leadership style variables on employee performance are 0.237 , as shown by the path coefficient. Judging from the T-value of 2.569 is more remarkable than 1.960 , and the value of P-values of 0.010 is smaller than the probability value of 0.05 or the value $(0.010 \leq 0.05)$ means that it is significant. This result means that there is a positive and significant influence of the participatory leadership style variables on employee performance, and the first hypothesis can be accepted.

2. The results of testing the hypothesis of the direction of the influence of Job Satisfaction Variables on Performance is 0.560 , as shown by the path coefficient. Seen from the T-value of 6.168 is more remarkable than 1,960, and P-values, 0,000 is smaller than the probability value of 0.05 or the value $(0,000 \leq 0.05)$ means that it is significant. There is a positive and 
significant influence of the Job Satisfaction Variable on Employee Performance so that the second hypothesis can be accepted.

3. Hypothesis test results stating that Job Satisfaction moderates the relationship of Participatory Leadership Style with Employee Performance is 0.125 as shown by the path coefficient. Seen from the T value of 2,028, it is smaller than 1.960 , and P-values 0.045 is smaller than the probability value of 0.05 or the value $(0.045 \leq 0.05)$ means that it is significant. There is a positive and significant influence, including quasi moderation (Solimun et al., 2017), meaning job satisfaction increases the influence of participatory leadership style on employee performance.

\section{DISCUSSION}

Based on the results of the first hypothesis proposed in this study, if the Participatory Leadership Style is high, the employee's performance will be higher. The test results show that Participatory Leadership Style's relationship with employee performance positively and significantly. This hypothesis can be accepted, meaning the better implementation of employees' participatory leadership styles, the higher the attitude of employee performance in the Cilegon Petrochemical Company. This finding is in line with research conducted by Huang et al.(2010) found a direct and robust relationship between participative leadership behavior and performance. These findings indicate that participatory leadership can influence performance through psychological mechanisms apart from motivational processes and exchange-based processes. According to research (Rokib \& Santoso, 2018; Setiawan, 2017), participative leadership style positively and significantly affects employee performance. Participatory leadership style empowers efforts with enthusiasm, motivation, and confidence to achieve the goals set. It can be said that the quality of leadership found in an organization plays a very dominant role in the success of the organization in carrying out its various activities, mostly seen in the performance of its employees (Siagian, 2009).

The second hypothesis proposed in this study is that if job satisfaction is high, work performance will be higher. The test results show that the relationship between job satisfaction and employee performance has a positive and significant effect, or this hypothesis can be accepted. The more satisfied the employee is with the company, the better the work shown will be, or vice versa. If someone feels satisfaction in their work, the performance will increase.

Satisfied employees have a positive attitude towards their work. Satisfied workers tend to be present to work on time, prioritize given targets, work quickly, work free from mistakes and neglect, loyalty and commitment to work, are less reliable, suggest new ideas, tend to increase knowledge, are willing to accept more many responsibilities, compliance with rules and regulations, lack of absenteeism and efforts to keep current jobs. A positive attitude will improve the quality and quantity of employee performance (Pushpakumari, 2008). This finding is in line with the previous studies showing that job satisfaction 
positively and significantly affect employee performance (Juniantara \& Riana, 2015; Nur, 2013).

Employee job satisfaction proves that the employees of the Petrochemical Cilegon Company can engage earnestly in their work. Each employee must have a different level of satisfaction according to the system and values adopted and obtained in all organizations. Job satisfaction always gets an essential place for organizational behavior in the organization where he works. These findings can be explained that job satisfaction can support the Participatory leadership style that is more leverage in the implementation of duties and work of employees. In other words, the organization prioritizes the role and reinforcement of the leadership style and harmonizes with the increase or strengthening in terms of job satisfaction expected by employees in work. The interaction of leadership style with job satisfaction in this study improves employee performance. This study's results are in line with the results of Tika's research (2013). It examines the influence of leadership style on employee performance with job satisfaction as a moderating variable, concluding that the satisfaction variable moderates a positive and significant influence between leadership style on employee performance.

\section{FURTHER STUDY}

Participatory Leadership Style has a positive and significant influence on the Employee Performance of Cilegon Petrochemical Company. The examination results found empirical evidence that moderation from job satisfaction strengthens the participative leadership style's influence on Cilegon Petrokima Company's employee performance. The moderation was positive and significant. The practical implication for managers, Job satisfaction, is an essential role in improving employee performance because an employee really needs job satisfaction to improve the performance of each individual even though according to its nature, job satisfaction itself is very relative or different from one person to another. Following the limitations of the study from the sample side, namely HRD employees, further research expanded the sample from a more diverse work unit.

\section{REFERENCES}

Aguirre-Urreta, M., \& Rönkkö, M. (2015). Sample size determination and statistical power analysis in PLS using R: An annotated tutorial. Communications of the Association for Information Systems, 36, 33-51. https://doi.org/10.17705/1cais.03603

Akehurst, G., Comeche, J. M., \& Galindo, M. A. (2008). Job satisfaction and commitment in the entrepreneurial SME. Springer, 32, 277-289. https://cyberleninka.org/article/n/900300/viewer

Culbertson, S. S. (2009). Do Satisfied Employees Mean Satisfied Customers? Academy of Management Perspectives, 23(1), 76-77. 
https://doi.org/10.5465/amp.2009.37008005

Dharma, Agus.(2004)ManajemenSupervisi. Jakarta: PT Raja GrafindoPersada.

Fatokun, J. O., Salaam, M. O., \& Ajegbomogun, F. O. (2010). The influence of leadership style on the performance of subordinates in Nigerian libraries. Library Philosophy and Practice, 2010(SEPTEMBER), 1-8.

Ferdinand, A. (2014). Metode Penelitian Manajemen Pedoman Penelitian untuk Penulisan Skripsi, Tesis, dan Disertasi Ilmu Manajemen (3rd ed.).

Fitrianasari, D., Nimran, U., \& Utami, H. (2013). Pengaruh Kompensasi dan Kepuasa Kerja Terhadap Organizational Citizenship Behavior (OCB) dan Kinerja Karyawan. Jurnal Profit, 7(1), 12-24. http://www.ejournalfia.ub.ac.id/index.php/profit/article/view/296

Fitriani. (2013). Pengaruh Gaya Kepemimpinan Partisipatif Terhadap Kinerja Pegawai Pada Dinas Pendidikan Provinsi Kalimantan Timur. eJournal Administrasi Negara, 1(3), 989-1002.

Gaver, J. J., Gaver, K. M., Austin, J. R., Gaver, J. J., Gaver, K. M., \& Austin, J. R. (1995). Additional evidence on bonus plans and income management. Journal of Accounting and Economics, 19(1), 3-28. https://econpapers.repec.org/RePEc:eee:jaecon:v:19:y:1995:i:1:p:3-28

Hair, J. F., Ringle, C. M., \& Sarstedt, M. (2011). PLS-SEM: Indeed a silver bullet. Journal of Marketing Theory and Practice, 19(2), 139-152. https://doi.org/10.2753/MTP1069-6679190202

Hamdollah, R., \& Baghaei, P. (2016). Partial least squares structural equation modeling with R. Practical Assessment, Research and Evaluation, 21(1), 1-16.

Handoko, T. H. (2012). . Manajemen Personalia dan Sumber Daya Manusia. BPFE. Hasibuan, M. (2008). Manajemen Sumber Daya Manusia. PT.Bumi Aksara.

Hijriah. (2016). Pengaruh Kepemimpinan Terhadap Pengembangan Sumber Daya Manusia di Lingkup Sekretariat Dewan Perwakilan Rakyat Daerah Kabupaten Mamuju Utara. E Jurnal Katalogis, 4(5), 37-50.

Huang, X., Iun, J., \& Gong, Y. (2010). Does Participative Leadership enchance Work Performance by Inducing Empowerment Or Trust? The Differential Effects On Managerial and Non Managerial Subordinates. Journal of Organizational Behavior, 31, 122-143. https://doi.org/10.1002/job.636

Insan, P. D., \& Yuniawan, A. (2016). Pengaruh Gaya Kepemimpinan Partisipatif, Lingkungan Kerja, Kompensasi dan Budaya Organisasi Terhadap Kinerja Karyawan (Studi Pada Bagian Keperawatan RSUD Tugurejo Semarang). DIPONEGORO JOURNAL OFMANAGEMENT, 5(1), 1-13.

Iqbal, S, A., \& N, H. (2015). Effect of Leadership Style on Employee Performance. Arabian Journal of Business and Management Review, 5(5), 1-6. https:// doi.org/10.4172/2223-5833.1000146

Jiputra, J. A. (2019). Pengaruh Kepemimpinan Partisipatif, Kepuasan Kerja dan Motivasi Kerja Terhadap Kinerja Karyawan Pada Divisi Penjualan Pt Rembaka. AGORA, 7(1).

Junaidi, Musnadi, S., \& Shabri, M. (2020). The Effect of Participative Leadership, Work Discipline, and Training on Employee Performance and Organizational Performance : Study At BKPSDM Pidie Jaya. International 
Journal of Business Management and Economic Review, 3(1), 17-27. https://doi.org/10.35409/ijbmer.2020.3135

Juniantara, I. W., \& Riana, I. G. (2015). Pengaruh Motivasi Dan Kepuasan Kerja Terhadap Kinerja Karyawan Koperasi DI Denpasar. E-Jurnal Ekonomi Dan Bisnis Universitas Udayana, 4(9), 611-628.

Lekić, N., Vapa-Tankosić, J., Rajaković-Mijailović, J., \& Lekić, S. (2019). An Analysis of factors influencing Employee Job Satisfaction In a Public Sector. E a M: Ekonomie a Management, 22(3), 83-99. https://doi.org/10.15240/tul/001/2019-3-006

Lumbasi, G. W., K, G. O., \& Ouma, C. A. (2016). The Effect of Achievement Oriented leadership Style on the Performance of COYA Senior Managers in Kenya. International Journal of Novel Research in Marketing Management and Economics, 3(2), 118-125. www.noveltyjournals.com

Luthans, F. (2006). Prilaku Organisasi (10th ed.). Andi.

Mangkunegara, A. A. A. P. (2016). Manajemen Sumber Daya Manusia Perusahaan. PT. Remaja Rosdakarya.

Mohajan, H. K. (2017). Aspects of mathematical economics, social choice and game theory: Jamal Nazrul Islam Research Centre for Mathematical Research. Journal of Economic Development, Environment and People, March. https://doi.org/10.13140/RG.2.2.16589.03040

Newman, A., Rose, P. S., \& Teo, S. T. T. (2016). The Role of Participative Leadership and Trust-Based Mechanisms in Eliciting Intern Performance: Evidence from China. Human Resource Management, 55(1), 2-20. https://doi.org/10.1002/hrm.21660

Nur, S. (2013). Konflik, Stres Kerja Dan Kepuasan Kerja Pengaruhnya Terhadap Kinerja Pegawai Pada Universitas Khairun Ternate. EMBA, 1(3), 739-749.

Ojokuku, R. M., Odetayo, T. A., \& Sajuyigbe, A. S. (2012). Impact of Leadership Style on Organizational Performance: A Case Study of Nigerian Banks. American Journal Of Business and Management, 1(4), 202-207.

Pushpakumari, M. D. (2008). The Impact of Job Satisfaction on Job Performance : An Empirical Analysis. City Forum, 9(1), 89-105. http://202.11.2.113/SEBM/ronso/no9_1/08_PUSHPAKUMARI.pdf

Putra, C. B., Utami, H. N., \& Hakam, M. S. (2013). Pengaruh Gaya Kepemimpinan Direktif, Suportif, Dan Partisipatif Terhadap Kinerja Karyawan (Studi pada PT. Astra Internasional Tbk. Daihatsu Malang). Jurnal Administrasi Bisnis (JAB), 2(2), 11-20. https://doi.org/10.1017/CBO9781107415324.004

Rana, R., Ka'ol, G., \& Kirubi, M. (2019). Effect of Participative Leadership Employee Performance of Coffee Trading Companies in Kenya. Journal of Human Resource and Leadership (JHRL), 7(6). https://doi.org/10.24940/theijbm/2019/v7/i6/bm1906-035

Rego, A. M. M. Do. (2014). Pengaruh Imbalan, Motivasi dan Kepuasan Kerja Terhadap Kinerja Pegawai Kejaksaan Agung Dan Kejaksaan Distrik Dili. EJurnal Ekonomi Dan Bisnis Universitas Udayana, 3(10), 599-613.

Rivai, V., Ramlly, M., Mutis, T., \& Arafah, W. (2014). Manajemen Sumber Daya Manusia Untuk Perusahaan (3rd ed.). Raja grafindo persada. 
Robbin, S. P., \& Judge, T. A. (2014). Prilaku Organisasi (16th ed.). Salemba Empat. Rokib, M. N., \& Santoso, D. (2018). Pengaruh Gaya Kepemimpinan Partisipatif dan Komunikasi Organisasi Terhadap Kinerja Karyawan Melalui Kepuasan Kerja sebagai Variabel Intervening. 4800, 108-127.

Sari, O. R., \& Susilo, H. (2018). Pengaruh Kepuasan Dan Motivasi Kerja Terhadap Kinerja Karyawan Dengan Organizational Citizenship Behavior Sebagai Variabel Intervening. JUrnal Administrasi Bisnis, 64(1), 28-35. https://doi.org/10.15294/maj.v4i1.7221

Setiawan, A. (2017). Pengaruh Gaya Kepemimpinan Partisipatif Terhadap Kinerja Karyawan Melalui Motivasi Kerja dan Kepuasan Kerja. AGORA, $5(3), 1-7$.

Siagian, S. P. (2009). Manajemen Sumber Daya Manusia (17th ed.). Bumi Aksara.

Solimun, Fernandes, A. A. R., \& Nurjannah. (2017). Metode Statistika Multivariat Pemodelan Persamaan Struktural (SEM) Pendekatan WarpPLS. Universitas Brawijawaya Pres (UB Press).

Stephen P. Robbins, T. A. J. (2013). Perilaku Organisasi: Organizational Behavior Buku 2 -12/E. Salemba Empat.

Sugiyono. (2013). Metode Penelitian Manajemen (Setiyawami (ed.)). Alfabeta.

Wibowo. (2013). Perilaku Dalam Organisasi. Rajawali Pers.

Williams, C. (2007). Research Methods. Journal of Business \& Economic Research, $5(3), 65-72$.

Wisudaningsi, B. A., Arofah, I., \& Belang, K. A. (2019). Pengaruh Kualitas Pelayanan Dan Kualitas Produk Terhadap Kepuasan Konsumen Dengan Menggunakan Metode Analisis Regresi Linear Berganda. Statmat: Jurnal Statistika Dan Matematika, 1(1), 103-116. https://doi.org/10.32493/sm.v1i1.2377 